\title{
Christelle Jullien. « La révolte des chrétiens au Hūzestān (551) : modèles narratifs d'une historiographie »
}

\section{Marie-Joseph Pierre}

\section{(2) OpenEdition}

1 Journals

\section{Édition électronique}

URL : http://journals.openedition.org/abstractairanica/42759

DOI : 10.4000/abstractairanica.42759

ISBN : 1961-960X

ISSN : 1961-960X

Éditeur :

CNRS (UMR 7528 Mondes iraniens et indiens), Éditions de l'IFRI

\section{Référence électronique}

Marie-Joseph Pierre, « Christelle Jullien. «La révolte des chrétiens au Hūzestān (551) : modèles narratifs d'une historiographie » », Abstracta Iranica [En ligne], Volume 37-38-39 | 2018, document 9, mis en ligne le 10 mars 2018, consulté le 02 octobre 2020. URL : http://journals.openedition.org/ abstractairanica/42759; DOI : https://doi.org/10.4000/abstractairanica.42759

Ce document a été généré automatiquement le 2 octobre 2020.

Tous droits réservés 


\title{
Christelle Jullien. « La révolte des chrétiens au Hūuzestān (551) : modèles narratifs d'une historiographie »
}

\author{
Marie-Joseph Pierre
}

\section{RÉFÉRENCE}

Christelle Jullien. «La révolte des chrétiens au Hūzestān (551) : modèles narratifs d'une historiographie », Bulletin of the Asia Institute 25, 2015, p. 107-120.

1 La révolte d'Anōšagzād, fils aîné de Husraw I ${ }^{\text {er }}$, en 551, marqua un épisode mouvementé de l'histoire des chrétiens de la province du Hūzestān. L'Histoire du catholicos Mār Abba conjuguée à la Chronique de Séert constitue un témoignage de premier ordre pour appréhender la perception historiographique des chrétiens syriaques sur la révolte, fournissant par ailleurs des données parfois inédites et non explorées qui permettent souvent d'éclairer les récits des littérateurs postérieurs, notamment Dīnawarī et Firdowsī, et d'en mieux comprendre les sources d'inspiration. L'analyse des structures narratives et du contexte d'insertion de l'épisode de la révolte dans un ensemble de récits concernant des chrétiens byzantins permet de réévaluer l'image d'Anōšagzād construite par les auteurs persans, et le rôle effectif des chrétiens dans cet événement. 


\section{AUTEURS}

\section{MARIE-JOSEPH PIERRE}

Directrice d'Études honoraire, EPHE 